\title{
Lentibacillus persicus sp. nov., a moderately halophilic species isolated from a saline lake
}

Correspondence

A. Ventosa

ventosa@us.es

\author{
C. Sánchez-Porro, ${ }^{1}$ M. A. Amoozegar, ${ }^{2}$ A. B. Fernandez, ${ }^{1}$ \\ H. Babavalian fard, ${ }^{2}$ M. Ramezani ${ }^{2}$ and A. Ventosa ${ }^{1}$
}

\author{
${ }^{1}$ Department of Microbiology and Parasitology, Faculty of Pharmacy, University of Sevilla, 41012 \\ Sevilla, Spain \\ ${ }^{2}$ Extremophiles Laboratory, Department of Microbiology, Faculty of Biology, College of Science, \\ University of Tehran, Tehran, Iran
}

\begin{abstract}
A Gram-staining-positive, moderately halophilic bacterium, designated strain $\mathrm{Amb} 31^{\top}$, was isolated from water of the hypersaline lake Aran-Bidgol in Iran and characterized taxonomically using a polyphasic approach. Cells were rods, motile and able to produce ellipsoidal endospores at a central position in swollen sporangia. Strain Amb31 ${ }^{\top}$ was facultatively anaerobic and catalase- and oxidase-positive. The strain grew in a complex medium supplemented with 3-25\% (w/v) $\mathrm{NaCl}$ (optimum 7.5-10\%). Optimal growth was at $30-35{ }^{\circ} \mathrm{C}$ and $\mathrm{pH} 7.5$. Phylogenetic analysis based on $16 \mathrm{~S}$ rRNA gene sequence comparisons showed that strain $\mathrm{Amb} 31^{\top}$ belonged to the genus Lentibacillus; it exhibited 16S rRNA gene sequence similarity values of 96.8 and $96.4 \%$ to Lentibacillus salicampi SF $-20^{\top}$ and Lentibacillus salinarum AHS $-1^{\top}$, respectively, and values of 95.9-94.7\% to the type strains of other recognized species of Lentibacillus. The cellwall peptidoglycan of strain Amb31 ${ }^{\top}$ was based on meso-diaminopimelic acid and MK-7 was the respiratory isoprenoid quinone. The major fatty acids were anteiso- $\mathrm{C}_{15: 0}(44.7 \%)$, iso- $\mathrm{C}_{16: 0}$ $(21.4 \%)$ and anteiso- $\mathrm{C}_{17: 0}(15.9 \%)$ and the polar lipid pattern consisted of phosphatidylglycerol, diphosphatidylglycerol, five phospholipids and a glycolipid. The DNA G+C content was $44.1 \mathrm{~mol} \%$. All these features confirmed the placement of strain $A \mathrm{mb} 31^{\top}$ within the genus Lentibacillus and the strain could be clearly differentiated from strains of the other species of Lentibacillus on the basis of several phenotypic, genotypic and chemotaxonomic features. DNA-DNA relatedness with the type strain of the most closely related strain, $L$. salicampi DSM $16425^{\top}$, was $28 \%$. Therefore, strain Amb31 $1^{\top}$ represents a novel species of the genus Lentibacillus, for which the name Lentibacillus persicus sp. nov. is proposed. The type strain is Amb31 $1^{\top}\left(=\right.$ CCM $7683^{\top}=$ CECT $7524^{\top}=$ DSM $22530^{\top}=$ LMG $\left.25304^{\top}\right)$.
\end{abstract}

The genus Lentibacillus was described by Yoon et al. (2002) to accommodate a single species, Lentibacillus salicampi, isolated from a salt field of the Yellow Sea in Korea. Namwong et al. (2005) described Lentibacillus juripiscarius, isolated from sauce produced in Thailand by the fermentation of fish. Jeon et al. (2005) described a third species within this genus, Lentibacillus salarius, isolated from saline sediment of a salt lake in China, and emended the description of the genus. This genus includes Gramvariable rods that are catalase-positive, oxidase-variable and urease-negative. The cell-wall peptidoglycan contains meso-diaminopimelic acid, and the predominant mena-

The GenBank/EMBL/DDBJ accession number for the 16S rRNA gene sequence of strain Amb31 ${ }^{\top}\left(=\mathrm{CS}-2009^{\top}\right)$ is FN376846.

Fatty acid compositions of strain $A m b 31^{\top}$ and type strains of the genus Lentibacillus are available as supplementary material with the online version of this paper. quinone is MK-7. The major polar lipids are diphosphatidylglycerol and phosphatidylglycerol and the major fatty acids are anteiso- $\mathrm{C}_{15: 0}$ and iso- $\mathrm{C}_{16: 0}$. The $\mathrm{G}+\mathrm{C}$ content of the DNA of this genus is in the range $42-$ $44 \mathrm{~mol} \%$ (Jeon et al., 2005). At the time of writing, the genus Lentibacillus includes six additional species: Lentibacillus lacisalsi from a salt lake in China (Lim et al., 2005), Lentibacillus halophilus from a fish-sauce fermentation (Tanasupawat et al., 2006) and Lentibacillus kapialis from fermented shrimp paste (Pakdeeto et al., 2007) produced in Thailand, Lentibacillus halodurans from a sediment sample of a salt lake in China (Yuan et al., 2007), Lentibacillus salinarum from a marine solar saltern of the Yellow Sea, Korea (Lee et al., 2008a), and Lentibacillus salis from soil of a salt lake in China (Lee et al., 2008b). All these species are considered moderately halophilic (Ventosa et al., 1998) and grow optimally at $4-15 \% \mathrm{NaCl}$, except L. halophilus, which is an extreme halophile with optimal 
growth at $20-26 \% \mathrm{NaCl}$ (Tanasupawat et al., 2006). Here we report on the taxonomic characterization of a novel bacterial strain, $A m b 31^{\mathrm{T}}$, which was isolated from a hypersaline lake in Iran by using a polyphasic approach and represents a novel Lentibacillus species.

Strain $A m b 31^{\mathrm{T}}$ was isolated from water of the hypersaline lake Aran-Bidgol, the largest playa in the centre of Iran $\left(35.7047^{\circ} \mathrm{N} 51.3962^{\circ} \mathrm{E}\right)$, which is situated $1000 \mathrm{~km}$ from the coast and at an altitude of $800 \mathrm{~m}$. This playa was formed by the deposition of halite sediments in different geological periods. The lake is triangular and has an area of about $650 \mathrm{~km}^{2}$. The predominant salts in this lake are $\mathrm{NaCl}, \mathrm{Na}_{2} \mathrm{SO}_{4}, \mathrm{MgCl}_{2}$ and $\mathrm{MgSO}_{4}$ and there are traces of carbonate ions. The salinity reaches saturation. The $\mathrm{pH}$ of the water is neutral (about pH 7.0-7.5). Strain Amb31 ${ }^{\mathrm{T}}$ was isolated by diluting a water sample in sterile $10 \%$ $(\mathrm{w} / \mathrm{v})$ salt solution, plating on $10 \% \mathrm{HM}$ medium, which contained $\left(\mathrm{l}^{-1}\right) 81 \mathrm{~g} \mathrm{NaCl}, 7 \mathrm{~g} \mathrm{MgCl}_{2}, 9.6 \mathrm{~g} \mathrm{MgSO}_{4}, 0.36 \mathrm{~g}$ $\mathrm{CaCl}_{2}, 2 \mathrm{~g} \mathrm{KCl}, 0.06 \mathrm{~g} \mathrm{NaHCO}_{3}, 0.026 \mathrm{~g} \mathrm{NaBr}, 3.5 \mathrm{~g}$ proteose-peptone, $10 \mathrm{~g}$ yeast extract and $1 \mathrm{~g}$ glucose (pH 7.5; Ventosa et al., 1982), and incubating aerobically at $35{ }^{\circ} \mathrm{C}$. The strain was purified three times by subsequent plating on the same medium and maintained on $10 \% \mathrm{HM}$ agar and at $-80{ }^{\circ} \mathrm{C}$ in $\mathrm{HM}$ broth supplemented with $30 \%$ (v/v) glycerol. L. salicampi DSM $16425^{\mathrm{T}}$ was used as a reference strain and was cultured under the same conditions as strain $A m b 31^{\mathrm{T}}$.

Cell morphology was examined by light microscopy (model CX 31; Olympus) using cells from exponentially growing cultures. Gram staining was performed by the Burke method (Murray et al., 1994) and the result was confirmed by the KOH test (Baron \& Finegold, 1990). The presence of endospores was investigated by using the Schaeffer-Fulton staining method (Murray et al., 1994). Motility was analysed by the wet-mount method (Murray et al., 1994). To determine the optimal temperature and $\mathrm{pH}$ for growth of the strain, broth cultures were incubated at $10-50{ }^{\circ} \mathrm{C}$ at intervals of $5{ }^{\circ} \mathrm{C}$ and at $\mathrm{pH} 5-11$ at intervals of $0.5 \mathrm{pH}$ units (using sodium acetate/acetic acid, Tris/HCl or glycine/sodium hydroxide to adjust the medium to $\mathrm{pH}<6,6-9$ and $>9$, respectively). Growth at $0,2.5,5,7.5$, $10,15,20,25$ and $30 \%(\mathrm{w} / \mathrm{v}) \mathrm{NaCl}$ was tested on $\mathrm{HM}$ medium at $\mathrm{pH}$ 7.5. Growth was monitored by $\mathrm{OD}_{600}$ using a spectroscopic method (model UV-160 A; Shimadzu). Catalase, oxidase and urease activities, nitrate reduction, aesculin hydrolysis, indole production and methyl red and Voges-Proskauer tests were examined as recommended by Smibert \& Krieg (1994). Hydrolysis of Tweens 20, 40, 60 and 80 was examined as described by Harrigan \& McCance (1976). Determination of acid production from carbohydrates, as well as utilization of carbon and nitrogen sources, was performed as recommended by Ventosa et al. (1982). Antibiotic susceptibility tests were performed on Mueller-Hinton agar plus $10 \%$ (w/v) sea salts (Ventosa et al., 1982) seeded with a bacterial suspension containing $1.5 \times 10^{6}$ c.f.u. $\mathrm{ml}^{-1}$ using discs impregnated with various antibiotics (HiMedia). The plates were incubated at $35{ }^{\circ} \mathrm{C}$ for $48 \mathrm{~h}$ and inhibition zone was interpreted according the manufacturer's manual. Other physiological and biochemical tests were performed as described previously (Mata et al., 2002; Quesada et al., 1984; Ventosa et al., 1982).

Strain $A m b 31^{\mathrm{T}}$ was a Gram-staining-positive, motile rod and produced ellipsoidal endospores at a central position in swollen sporangia. When grown for 2 days at $35{ }^{\circ} \mathrm{C}$ on $10 \%$ HM medium, colonies were circular, entire, convex, smooth and cream coloured, with a diameter of 1.5$2.0 \mathrm{~mm}$. Strain $\mathrm{Amb} 31^{\mathrm{T}}$ was moderately halophilic, growing with 3-25\% (w/v) $\mathrm{NaCl}$ (optimally with 7.5-10\% $\mathrm{NaCl}$ ). No growth was observed in the absence of $\mathrm{NaCl}$. The isolate grew between $\mathrm{pH} 6.0$ and 9.5 (optimally at $\mathrm{pH} 7.5$ ) and at $15-50{ }^{\circ} \mathrm{C}$ (optimally at $30-35^{\circ} \mathrm{C}$ ). Other phenotypic features are included in Table 1 and the species description.

Genomic DNA from strain $A m b 31^{\mathrm{T}}$ was prepared using the method described by Marmur (1961). The 16S rRNA gene was amplified by PCR with the forward primer $16 \mathrm{~F} 27$ [5'-AGAGTTTGATC(AC)TGGCTCAG-3'] and the reverse primer 16R1488 (5'-CGGTTACCTTGTTAGGACTTCACC-3'). Direct sequence determination of the PCRamplified DNA was carried out using an automated DNA sequencer model ABI 3130XL (Applied Biosystems). 16S rRNA gene sequence analysis was performed with the ARB software package (Ludwig et al., 2004). Published sequences from closely related bacteria were aligned with that from strain $A m b 31^{\mathrm{T}}$ and the alignment was confirmed and checked against both primary and secondary structures of the 16S rRNA molecule using the alignment tool of the ARB software package. Phylogenetic trees were constructed using neighbour-joining (Saitou \& Nei, 1987), maximumlikelihood (Felsenstein, 1981) and maximum-parsimony (Fitch, 1971) algorithms in the ARB software.

An almost-complete $16 \mathrm{~S}$ rRNA gene sequence (1480 bp) of strain $A m b 31^{\mathrm{T}}$ was obtained and used for initial BLAST searches in GenBank and for phylogenetic analysis. Identification of phylogenetic neighbours and calculation of pairwise $16 \mathrm{~S}$ rRNA gene sequence similarity were achieved using the EzTaxon server (http://www.eztaxon. org; Chun et al., 2007). Phylogenetic analysis based on the neighbour-joining algorithm revealed that strain Amb31 ${ }^{\mathrm{T}}$ was included in the cluster of strains of the genus Lentibacillus (Fig. 1). The most closely related strains were L. salicampi SF- $20^{\mathrm{T}}(96.8 \% 16 \mathrm{~S}$ rRNA gene sequence similarity), L. salinarum AHS- $1^{\mathrm{T}}(96.4 \%)$ and L. halodurans $8-1^{\mathrm{T}}(95.9 \%)$; similarities with the other Lentibacillus strains were 95.6-94.7\%. Other closely related strains were the type strains of Virgibacillus kekensis (95.3\% sequence similarity), Virgibacillus olivae $\mathrm{E}_{30} 8^{\mathrm{T}}(95.1 \%)$ and Virgibacillus marismortui $123^{\mathrm{T}} \quad(95.0 \%)$. Maximumlikelihood and maximum-parsimony methods resulted in highly similar tree topologies (not shown) and confirmed the phylogenetic cluster formed by strain $A m b 31^{\mathrm{T}}$ and strains of the genus Lentibacillus. 
Table 1. Characteristics that distinguish strain Amb31 ${ }^{\top}$ from strains of the genus Lentibacillus

Strains: 1, Lentibacillus persicus sp. nov. Amb31 ${ }^{\mathrm{T}}$; 2, L. salicampi JCM $11462^{\mathrm{T}}$ (unless indicated, data from Yoon et al., 2002); 3, L. salinarum KCTC $13162^{\mathrm{T}}$ (Lee et al., 2008a); 4, L. halodurans DSM $18342^{\mathrm{T}}$ (Yuan et al., 2007); 5, L. juripiscarius JCM 12147 ${ }^{\mathrm{T}}$ (Namwong et al., 2005); 6, L. kapialis JCM $12580^{\mathrm{T}}$ (Pakdeeto et al., 2007); 7, L. salarius KCTC $3911^{\mathrm{T}}$ (Jeon et al., 2005); 8, L. salis KCTC 3936 ${ }^{\mathrm{T}}$ (Lee et al., 2008b); 9, L. lacisalsi KCTC $3915^{\mathrm{T}}$ (Lim et al., 2005); 10, L. halophilus JCM $12149^{\mathrm{T}}$ (Tanasupawat et al., 2006). +, Positive; -, negative; ND, no data available.

\begin{tabular}{|c|c|c|c|c|c|c|c|c|c|c|}
\hline Characteristic & 1 & 2 & 3 & 4 & 5 & 6 & 7 & 8 & 9 & 10 \\
\hline Cell width $(\mu \mathrm{m})$ & 0.9 & $0.4-0.7$ & $0.7-1.2$ & 0.5 & $0.4-0.5$ & $0.2-0.4$ & $0.2-0.3$ & $0.4-0.6$ & $0.4-0.6$ & $0.4-0.6$ \\
\hline Cell length $(\mu \mathrm{m})$ & $1.5-4.0$ & $2.0-4.0$ & $2.0-4.0$ & $1.5-2.5$ & $1.5-6.0$ & $0.8-2.5$ & $1.5-3.0$ & $0.8-2.5$ & $1.2-3.0$ & $1.0-3.0$ \\
\hline Endospore shape $\dagger$ & $\mathrm{E}$ & $\mathrm{SP}-\mathrm{O}$ & o & $\mathrm{SP}-\mathrm{O}$ & $\mathrm{O}$ & $\mathrm{SP}$ & $\mathrm{SP}-\mathrm{O}$ & $\mathrm{SP}$ & $\mathrm{SP}$ & $\mathrm{SP}$ \\
\hline Pigmentation $\neq$ & $\mathrm{CR}$ & $\mathrm{CR}$ & $\mathrm{CR}-\mathrm{Y}$ & WH & $\mathrm{WH}-\mathrm{CR}$ & $\mathrm{R}$ & $\mathrm{CR}$ & LY & $\mathrm{CR}$ & $\mathrm{WH}-\mathrm{CR}$ \\
\hline Range & $3-25$ & $2-23$ & $3-24$ & $5-30$ & $3-30$ & $5-30$ & $1-20$ & $5-15$ & $5-25$ & $12-30$ \\
\hline Optimum & $7.5-10.0$ & $4-8$ & $10-12$ & $8-12$ & 10 & 15 & $12-14$ & 10 & $12-15$ & $20-26$ \\
\hline \multicolumn{11}{|l|}{$\mathrm{pH}$ for growth } \\
\hline Range & $6.0-9.5$ & $5.0-8.5 \S$ & $6-9.5$ & $6-9$ & $5-9$ & $5-9$ & $6-8.5$ & $7-9.2$ & $7-9.5$ & $6-8$ \\
\hline Optimum & 7.5 & 6-8 & $6.5-7$ & $7-7.5$ & 7 & 7 & $7-7.5$ & 8 & 8 & $7-7.5$ \\
\hline Nitrate reduction & + & + & + & - & + & + & + & + & + & - \\
\hline \multicolumn{11}{|l|}{ Hydrolysis of: } \\
\hline Aesculin & - & - & + & - & - & - & + & - & - & - \\
\hline Casein & + & + & - & - & + & - & - & - & - & - \\
\hline Tween 80 & - & + & - & - & + & - & - & - & - & - \\
\hline Urea & - & - & - & - & - & + & - & - & - & - \\
\hline \multicolumn{11}{|l|}{ Acid production from: } \\
\hline D-Fructose & + & - & - & + & + & + & + & + & + & - \\
\hline D-Glucose & + & -11 & + & + & + & + & + & + & - & - \\
\hline Lactose & - & - & - & - & - & - & + & - & - & - \\
\hline Maltose & - & - & - & - & - & - & + & - & - & - \\
\hline
\end{tabular}

${ }^{*} \mathrm{C}$, Central; s, swollen; ss, swollen sporangia; $\mathrm{T}$, terminal.

$\dagger \mathrm{\dagger}$, Ellipsoidal; O, oval; sP, spherical.

\$CR, Cream; LY, light yellow; R, red; WH, white; Y, yellow.

§Data for L. salicampi DSM $16425^{\mathrm{T}}$ obtained in this study.

IIPositive results were obtained for L. salicampi DSM $16425^{\mathrm{T}}$ in this study.

SRange of values for 13 strains including the type strain.

The $\mathrm{G}+\mathrm{C}$ content of the genomic DNA was determined from the midpoint value $\left(T_{\mathrm{m}}\right)$ of the thermal denaturation profile (Marmur \& Doty, 1962) by using the equation of Owen \& Hill (1979). Cell biomass for analysis of the cell-wall peptidoglycan, isoprenoid quinones and polar lipids was obtained by cultivation on $10 \% \mathrm{HM}$ agar at $35{ }^{\circ} \mathrm{C}$. The cellwall peptidoglycan type, respiratory lipoquinone and polar lipids of strain Amb31 $1^{\mathrm{T}}$ were analysed by the Identification
Service and Dr B. J. Tindall at DSMZ, Braunschweig, Germany. For the fatty acid determination, cells were grown on marine agar (Difco) with $10 \% \mathrm{NaCl}(\mathrm{pH} 7.2)$ at $37{ }^{\circ} \mathrm{C}$ for $48 \mathrm{~h}$. The whole-cell fatty acid composition was determined by gas chromatography with the Microbial Identification System (MIDI) by the Identification, Characterization and Molecular Typing Service at the BCCM/LMG Bacteria Collection, Gent, Belgium. 


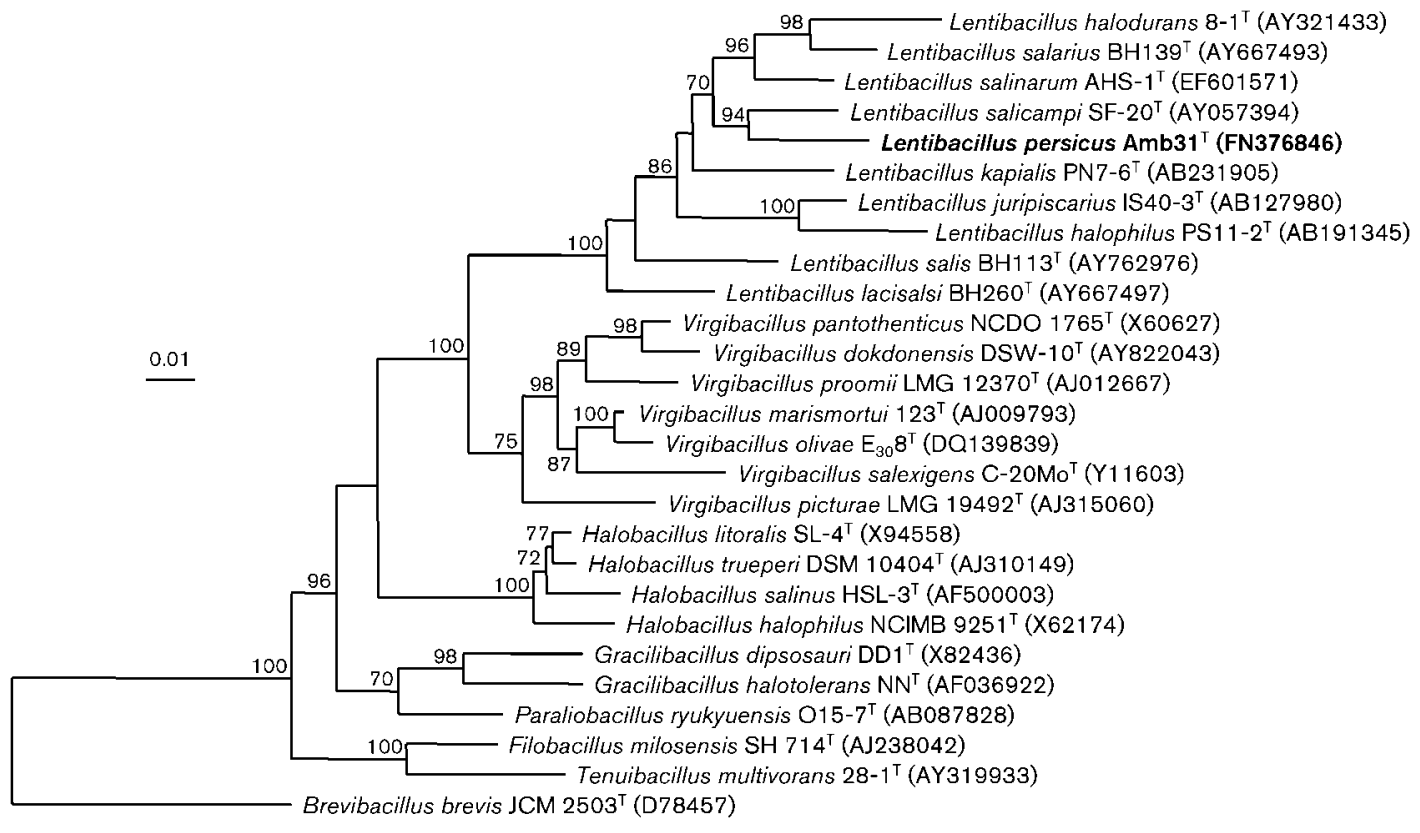

Fig. 1. Neighbour-joining phylogenetic tree, based on the 16S rRNA gene sequence comparison, showing the relationship of strain $A m b 31^{\top}$ with related strains of the genera Lentibacillus, Virgibacillus, Halobacillus, Gracilibacillus, Paraliobacillus, Filobacillus and Tenuibacillus. Bootstrap values $(\geqslant 70 \%)$ based on 1000 replications are shown as percentages at branch nodes. Brevibacillus brevis JCM $2503^{\top}$ was used as an outgroup. Bar, 0.01 substitutions per nucleotide position.

The $\mathrm{G}+\mathrm{C}$ content of the DNA of strain $A m b 31^{\mathrm{T}}$ was $44.1 \mathrm{~mol} \%$. This value is within the range described for Lentibacillus species (Table 1). The polar lipids detected were phosphatidylglycerol, diphosphatidylglycerol, five phospholipids and an unidentified glycolipid. Strain Amb3 $31^{\mathrm{T}}$ contained MK-7 as the unique menaquinone and the peptidoglycan cell-wall type A1 $\gamma$, with mesodiaminopimelic acid as the diagnostic diamino acid. These features are defined characteristics for the genus Lentibacillus (Jeon et al., 2005). The cellular fatty acid profile of strain Amb31 ${ }^{\mathrm{T}}$ is shown in Supplementary Table S1 (available in IJSEM Online). The predominant fatty acids are anteiso- $\mathrm{C}_{15: 0}(44.7 \%)$, iso- $\mathrm{C}_{16: 0}(21.4 \%)$ and anteiso- $\mathrm{C}_{17: 0}(15.9 \%)$, which are the major fatty acids detected in Lentibacillus species (Jeon et al., 2005).

DNA-DNA hybridization studies were performed by the competition procedure of the membrane method (Johnson, 1994) described in detail by Arahal et al. (2001a, b). The hybridization temperature was $47.9^{\circ} \mathrm{C}$, which is within the limit of validity for the filter method (De Ley \& Tijtgat, 1970), and the percentage of hybridization was calculated according to Johnson (1994). The experiments were carried out in triplicate. The percentage of DNA-DNA hybridization between strain Amb $31^{\mathrm{T}}$ and L. salicampi DSM $16425^{\mathrm{T}}$ was $28 \%$. This level of DNA-DNA relatedness is low enough to classify strain Amb31 ${ }^{\mathrm{T}}$ within a genotypically distinct novel species of Lentibacillus (Stackebrandt \& Goebel, 1994; Stackebrandt et al., 2002).
Overall, our results show clearly that strain $A m b 31^{T}$ is phylogenetically closely related to strains of the genus Lentibacillus; however, there are differences in some phenotypic and chemotaxonomic features (Table 1). Therefore, we propose that the strain represents a novel species of the genus Lentibacillus, for which the name Lentibacillus persicus sp. nov. is proposed.

\section{Description of Lentibacillus persicus sp. nov.}

Lentibacillus persicus [per'si.cus. L. masc. adj. persicus Persian, pertaining to Persia (Iran), from where the type strain was isolated].

Cells are Gram-staining-positive motile rods, $0.9 \times 1.5-$ $4.0 \mu \mathrm{m}$. Ellipsoidal endospores form at a central position in swollen sporangia. Colonies are cream coloured, circular, convex and smooth with entire margins and are 1.5$2.0 \mathrm{~mm}$ in diameter after 2 days of incubation at $35{ }^{\circ} \mathrm{C}$ on $10 \%$ HM medium. Facultatively anaerobic. Catalase- and oxidase-positive but urease-negative. Moderately halophilic. Requires 3-25\% NaCl for growth (optimum 7.5-10\% $\mathrm{NaCl}$ ); no growth without $\mathrm{NaCl}$. Grows at $15-50{ }^{\circ} \mathrm{C}$ (optimum $30-35{ }^{\circ} \mathrm{C}$ ) and $\mathrm{pH}$ 6.0-9.5 (optimum $\mathrm{pH}$ 7.5). Reduces nitrate and nitrite. Hydrolyses casein, gelatin, Tweens 40 and 60 and DNA, but not starch, Tweens 20 or 80 , aesculin, tyrosine, xanthine or hypoxanthine. Indole and $\mathrm{H}_{2} \mathrm{~S}$ are not produced. Methyl red and VogesProskauer tests are negative. Arginine dihydrolase and ornithine and lysine decarboxylases are not detected. Produces acid from D-fructose, D-glucose, D-ribose and 
trehalose, but not from D-amygdalin, D-arabinose, arbutin, cellobiose, L-citrulline, dulcitol, DL-methionine, D-galactose, glycerol, myo-inositol, inulin, lactose, maltose, D-mannitol, D-mannose, melezitose, melibiose, raffinose, sorbitol, sucrose, xylitol or D-xylose. The following compounds are used as sole carbon and energy sources: fructose, Dglucose, maltose, ribose, sucrose, trehalose, aesculin, melezitose, butanol, myo-inositol, xylitol, acetate, benzoate, ethanol, fumarate, glycerol and hippurate. The following compounds are not used as sole carbon and energy sources: starch, D-arabinose, cellobiose, D-fucose, D-galactose, lactose, D-mannose, melibiose, raffinose, D-xylose, salicin, dulcitol, D-mannitol, propanol, D-sorbitol, methanol, citrate, formate, propionate, succinate, valerate, malate and tartrate. The following compounds are used as sole carbon, nitrogen and energy sources: L-alanine, glutamine, L-lysine and L-threonine. The following compounds are not used as sole carbon, nitrogen and energy sources: Larginine, aspartate, L-cysteine, phenylalanine, L-methionine, L-ornithine, L-serine, tryptophan, isoleucine and valine. Sensitive to ( $\mu \mathrm{g}$ per disc unless otherwise indicated) amikacin (30), amoxicillin (30) bacitracin (10 U), carbenicillin (100), cefoxitin (30), chloramphenicol (30), erythromycin (15), gentamicin (30), nitrofurantoin (300), novobiocin (5), rifampicin (5), streptomycin (10), tetracycline (30) and tobramycin (10). Resistant to kanamycin (30) and polymixin B (100 U). Peptidoglycan contains meso-diaminopimelic acid. The menaquinone is MK-7. Major fatty acids are anteiso- $\mathrm{C}_{15: 0}$, iso- $\mathrm{C}_{16: 0}$ and anteiso$\mathrm{C}_{17: 0}$. Phosphatidylglycerol, diphosphatidylglycerol, five phospholipids and an unidentified glycolipid are present as major polar lipids. The DNA G $+\mathrm{C}$ content of the type strain is $44.1 \mathrm{~mol} \%\left(T_{\mathrm{m}}\right)$.

The type strain, Amb31 ${ }^{\mathrm{T}}\left(=\mathrm{CCM} 7683^{\mathrm{T}}=\right.$ CECT $7524^{\mathrm{T}}$ $=$ DSM $22530^{\mathrm{T}}=$ LMG $\left.25304^{\mathrm{T}}\right)$, was isolated from the hypersaline lake Aran-Bidgol in Iran.

\section{Acknowledgements}

We are grateful to Jean Euzéby for his help and valuable suggestions regarding the etymology. This study was supported by grants from the Iranian Environment Department (3/42274), the Spanish Ministerio de Educación y Ciencia (BIO2009-10138) and the Junta de Andalucía (P06-CVI-01829). FEDER funds cofinanced this study.

\section{References}

Arahal, D. R., García, M. T., Ludwig, W., Schleifer, K. H. \& Ventosa, A. (2001a). Transfer of Halomonas canadensis and Halomonas israelensis to the genus Chromohalobacter as Chromohalobacter canadensis comb. nov. and Chromohalobacter israelensis comb. nov. Int J Syst Evol Microbiol 51, 1443-1448.

Arahal, D. R., Garcia, M. T., Vargas, C., Cánovas, D., Nieto, J. J. \& Ventosa, A. (2001b). Chromohalobacter salexigens sp. nov., a moderately halophilic species that includes Halomonas elongata DSM 3043 and ATCC 33174. Int J Syst Evol Microbiol 51, 1457-1462.

Baron, E. J. \& Finegold, S. M. (1990). Bailey and Scott's Diagnostic Microbiology, 8th edn. St Louis: Mosby.
Chun, J., Lee, J.-H., Jung, Y., Kim, M., Kim, S., Kim, B. K. \& Lim, Y.-W. (2007). EzTaxon: a web-based tool for the identification of prokaryotes based on $16 \mathrm{~S}$ ribosomal RNA gene sequences. Int J Syst Evol Microbiol 57, 2259-2261.

De Ley, J. \& Tijtgat, R. (1970). Evaluation of membrane filter methods for DNA-DNA hybridization. Antonie van Leeuwenhoek 36, 461474.

Felsenstein, J. (1981). Evolutionary trees from DNA sequences: a maximum likelihood approach. J Mol Evol 17, 368-376.

Fitch, W. M. (1971). Toward defining the course of evolution: minimum change for a specific tree topology. Syst Zool 20, 406-416.

Harrigan, W. F. \& McCance, M. E. (1976). Laboratory Methods in Food and Dairy Microbiology. London: Academic Press.

Jeon, C. O., Lim, J. M., Lee, J. C., Lee, G. S., Lee, J. M., Xu, L. H., Jiang, C. L. \& Kim, C. J. (2005). Lentibacillus salarius sp. nov., isolated from saline sediment in China, and emended description of the genus Lentibacillus. Int J Syst Evol Microbiol 55, 1339-1343.

Johnson, J. L. (1994). Similarity analysis of DNAs. In Methods for General and Molecular Bacteriology, pp. 655-681. Edited by P. Gerhardt, R. G. E. Murray, W. A. Wood \& N. R. Krieg. Washington, DC: American Society for Microbiology.

Lee, S. Y., Choi, W. Y., Oh, T. K. \& Yoon, J. H. (2008a). Lentibacillus salinarum sp. nov., isolated from a marine solar saltern in Korea. Int $J$ Syst Evol Microbiol 58, 45-49.

Lee, J. C., Li, W. J., Xu, L. H., Jiang, C. L. \& Kim, C. J. (2008b). Lentibacillus salis sp. nov., a moderately halophilic bacterium isolated from a salt lake. Int J Syst Evol Microbiol 58, 1838-1843.

Lim, J. M., Jeon, C. O., Song, S. M., Lee, J. C., Ju, Y. J., Xu, L. H., Jiang, C. L. \& Kim, C. J. (2005). Lentibacillus lacisalsi sp. nov., a moderately halophilic bacterium isolated from a saline lake in China. Int J Syst Evol Microbiol 55, 1805-1809.

Ludwig, W., Strunk, O., Westram, R., Richter, L., Meier, H., Yadhukumar, Buchner, A., Lai, T., Steppi, S. \& other authors (2004). ARB: a software environment for sequence data. Nucleic Acids Res 32, 1363-1371.

Marmur, J. (1961). A procedure for the isolation of deoxyribonucleic acid from microorganisms. J Mol Biol 3, 208-218.

Marmur, J. \& Doty, P. (1962). Determination of the base composition of deoxyribonucleic acid from its thermal denaturation temperature. J Mol Biol 5, 109-118.

Mata, J. A., Martinez-Canovas, J., Quesada, E. \& Bejar, V. (2002). A detailed phenotypic characterization of the type strains of Halomonas species. Syst Appl Microbiol 25, 360-375.

Murray, R. G. E., Doetsch, R. N. \& Robinow, F. (1994). Determinative and cytological light microscopy. In Methods for General and Molecular Bacteriology, pp. 21-41. Edited by P. Gerhardt, R. G. E. Murray, W. A. Wood \& N. R. Krieg. Washington, DC: American Society for Microbiology.

Namwong, S., Tanasupawat, S., Smitinont, T., Visessanguan, W., Kudo, T. \& Itoh, T. (2005). Isolation of Lentibacillus salicampi strains and Lentibacillus juripiscarius sp. nov. from fish sauce in Thailand. Int J Syst Evol Microbiol 55, 315-320.

Owen, R. J. \& Hill, L. R. (1979). The estimation of base compositions, base pairing and genome sizes of bacterial deoxyribonucleic acids. In Identification Methods for Microbiologists (Society for Applied Bacteriology Technical Series no. 14), 2nd edn, pp. 277-296. Edited by F. A. Skinner \& D. W. Lovelock. London: Academic Press.

Pakdeeto, A., Tanasupawat, S., Thawai, C., Moonmangmee, S., Kudo, T. \& Itoh, T. (2007). Lentibacillus kapialis sp. nov., from fermented shrimp paste in Thailand. Int J Syst Evol Microbiol 57, 364369. 
Quesada, E., Ventosa, A., Ruiz-Berraquero, F. \& RamosCormenzana, A. (1984). Deleya halophila, a new species of moderately halophilic bacteria. Int J Syst Bacteriol 34, 287-292.

Saitou, N. \& Nei, M. (1987). The neighbour-joining method: a new method for reconstructing phylogenetic trees. Mol Biol Evol 4, 406425.

Smibert, R. M. \& Krieg, N. R. (1994). Phenotypic characterization. In Methods for General and Molecular Bacteriology, pp. 607-654. Edited by P. Gerhardt, R. G. E. Murray, W. A. Wood \& N. R. Krieg. Washington, DC: American Society for Microbiology.

Stackebrandt, E. \& Goebel, B. M. (1994). Taxonomic note: a place for DNA-DNA reassociation and $16 \mathrm{~S}$ rRNA sequence analysis in the present species definition in bacteriology. Int J Syst Bacteriol 44, 846849.

Stackebrandt, E., Fredericksen, W., Garrity, G. M., Grimont, P. A. D., Kämpfer, P., Maiden, M. C. J., Nesme, X., Rosselló-Mora, R., Swings, J. $\&$ other authors (2002). Report of the ad hoc committee for the re- evaluation of the species definition in bacteriology. Int J Syst Evol Microbiol 52, 1043-1047.

Tanasupawat, S., Pakdeeto, A., Namwong, S., Thawai, C., Kudo, T. \& Itoh, T. (2006). Lentibacillus halophilus sp. nov., from fish sauce in Thailand. Int J Syst Evol Microbiol 56, 1859-1863.

Ventosa, A., Quesada, E., Rodriguez-Valera, F., Ruiz-Berraquero, F. \& Ramos-Cormenzana, A. (1982). Numerical taxonomy of moderately halophilic Gram-negative rods. J Gen Microbiol 128, 1959-1968.

Ventosa, A., Nieto, J. J. \& Oren, A. (1998). Biology of moderately halophilic aerobic bacteria. Microbiol Mol Biol Rev 62, 504-544.

Yoon, J. H., Kang, K. H. \& Park, Y. H. (2002). Lentibacillus salicampi gen. nov., sp. nov., a moderately halophilic bacterium isolated from a salt field in Korea. Int J Syst Evol Microbiol 52, 2043-2048.

Yuan, S., Ren, P., Liu, J., Xue, Y., Ma, Y. \& Zhou, P. (2007). Lentibacillus halodurans sp. nov., a moderately halophilic bacterium isolated from a salt lake in Xin-Jiang, China. Int J Syst Evol Microbiol 57, 485-488. 